\title{
SYSTEM POLITYCZNY REPUBLIKI TUNEZJI PO REWOLUCJI JAŚMINOWEJ
}

\author{
Katarzyna Elżbieta Stachurska-Szczesiak \\ Uniwersytet Marii Curie-Skłodowskiej w Lublinie \\ Katedra Stosunków Międzynarodowych \\ ORCID ID: https://orcid.org/0000-0001-9179-0746 \\ e-mail: katarzyna.stachurska-szczesiak@poczta.umcs.lublin.pl
}

\begin{abstract}
Monika Kowalska
Uniwersytet Marii Curie-Skłodowskiej w Lublinie

Katedra Systemów Politycznych i Praw Człowieka

ORCID ID: https://orcid.org/0000-0002-0575-0463

e-mail: monika.kowalska@mail.umcs.pl
\end{abstract}

Streszczenie: Pokojowe obalenie w 2011 r. wieloletniego dyktatora Tunezji Zine el-Abidine Ben Alego (określane mianem rewolucji jaśminowej) stało się inspiracją dla Arabskiej Wiosny. Od tego czasu Tunezja wprowadziła daleko idące demokratyczne reformy, co na Zachodzie spotkało się z postrzeganiem jej jako jednego z nielicznych państw Bliskiego Wschodu i Maghrebu, w którym Arabska Wiosna odniosła sukces. Celem artykułu jest analiza ewolucji uwarunkowań politycznych, jakie dokonały się po rewolucji jaśminowej przez pryzmat ustanowienia nowej Konstytucji Republiki Tunezji z 2014 r. oraz wdrażania jej zasad u progu 2020 r. Punktem wyjścia tak określonego celu badań obok zagadnień systemowych jest uchwycenie zmian, jakie dokonały się w Republice Tunezji, przy uwzględnieniu uwarunkowań gospodarczych i społecznych oraz ich ocena. W tym kontekście metodologicznym nowa konstytucja będąca ucieleśnieniem oczekiwań społeczeństwa tunezyjskiego po $2011 \mathrm{r}$. wzmacnia i wyznacza nowe ramy dla procesu demokratycznego swojego państwa. Dla weryfikacji hipotezy badawczej wykorzystano następujące metody i techniki badawcze: analiza czynnikowa - w kontekście badania uwarunkowań politycznych, gospodarczych i społecznych; analiza zawartości dokumentów - w kontekście analizy treści nowej Konstytucji Republiki Tunezji; technika statystyczna - pomocna przy określeniu rzeczywistego procesu transformacji Tunezji w kierunku pełnej demokracji.

Słowa kluczowe: system polityczny Tunezji, rewolucja jaśminowa, Arabska Wiosna, Konstytucja Republiki Tunezji, transformacja 


\section{WPROWADZENIE}

Pokojowe obalenie w $2011 \mathrm{r}$. wieloletniego dyktatora Tunezji Zine el-Abidine Ben Alego (określane mianem rewolucji jaśminowej) stało się inspiracją dla Arabskiej Wiosny. Od tego czasu Tunezja wprowadziła daleko idące demokratyczne reformy, co na Zachodzie spotkało się z postrzeganiem jej jako jednego z nielicznych państw Bliskiego Wschodu i Maghrebu, w którym Arabska Wiosna odniosła sukces. Celem artykułu jest analiza ewolucji uwarunkowań politycznych, jakie dokonały się po rewolucji jaśminowej przez pryzmat ustanowienia nowej Konstytucji Republiki Tunezji z 2014 r. oraz wdrażania jej zasad u progu 2020 r. Punktem wyjścia tak określonego celu badań obok zagadnień systemowych jest uchwycenie zmian, jakie dokonały się w Republice Tunezji, przy uwzględnieniu uwarunkowań gospodarczych i społecznych oraz ich ocen. W tym kontekście metodologicznym nowa konstytucja będąca ucieleśnieniem oczekiwań społeczeństwa tunezyjskiego po 2011 r. wzmacnia i wyznacza nowe ramy dla procesu demokratycznego swojego państwa. Dla weryfikacji hipotezy badawczej wykorzystano następujące metody i techniki badawcze: analiza czynnikowa - w kontekście badania uwarunkowań politycznych, gospodarczych i społecznych; analiza zawartości dokumentów - w kontekście analizy treści nowej Konstytucji Republiki Tunezji; technika statystyczna - pomocna przy określeniu rzeczywistego procesu transformacji Tunezji w kierunku pełnej demokracji.

\section{ROZWIĄZANIA KONSTYTUCJI REPUBLIKI TUNEZJI Z 2014 ROKU}

Po rewolucji jaśminowej i zainicjowanych przemianach społeczno-politycznych będących jej wynikiem państwo tunezyjskie stanęło przed szansą wypełnienia aspiracji swoich obywateli domagających się wolności, równości i sprawiedliwości społecznej podczas protestów z przełomu 2010 i 2011 r. Przystępując do prac nad nową ustawą zasadniczą i kreśląc nową wizję Tunezji jako państwa opierającego się na prawach człowieka i rządach prawa, niezwykle ważne było, by nowa konstytucja zagwarantowała podział władzy, chroniła przed dyskryminacją, zapewniała wszystkim równość wobec prawa oraz podstawowe prawa i wolności, uwzględniała zasady rzetelnych i sprawiedliwych procesów sądowych oraz chroniła niezależność sądów. Poprzednia konstytucja z 1959 r. [Konstytucja Republiki Tunezji...] zawierała pewne przepisy chroniące prawa człowieka. Jednak pod rządami najpierw prezydenta Habiba Burgiby, a następnie Ben Alego była wielokrotnie nowelizowana, by umożliwić głowie państwa uzyskanie większej władzy [Bojarczyk 2004: 104-107]. Warto wspomnieć też, że Tunezja była pierwszym państwem w regionie, które przedstawiło po Arabskiej Wiośnie 2011 r. projekt swojej nowej konstytucji. 
Zgromadzenie Konstytucyjne wybrane w głosowaniu powszechnym 23 października 2011 r. początkowo miało mieć tylko rok na zredagowanie nowej konstytucji, ale jego prace uległy znacznej obstrukcji w wyniku sporu między islamistami a opozycją. Proces normalizacji opóźniał zwłaszcza konflikt między rządzącą islamską Partią Odrodzenia - Ennahda (ar. Hizb an-Nahda) a laicką opozycją w sprawie roli islamu w życiu politycznym Tunezji. Kryzys polityczny w państwie wpływający na paraliż prac konstytucyjnych pogłębiało również powstawanie zbrojnych grup dżihadystycznych i organizowane przez nie w państwie zamachy terrorystyczne (m.in. we wrześniu 2012 r. na ambasadę amerykańską) oraz przede wszystkim dokonanie zabójstw dwóch przywódców opozycji laickiej: Szokriego Belaida i Mohameda Brahmiego (zabójstwo pierwszego spowodowało dymisję rządu premiera Hamadego Dżebalego). By ułatwić wyjście z impasu, umiarkowani islamiści z Ennahdy zgodzili się przekazać władzę tymczasowemu technokratycznemu gabinetowi ${ }^{1}$ do czasu przeprowadzenia wyborów parlamentarnych i uchwalenia konstytucji.

Przyjęcie nowej ustawy zasadniczej nie było łatwe. Konstytuanta pracowała nad projektem ponad dwa lata. Jednak należy docenić, że zarówno islamiści z Ennahdy, ich sprzymierzeńcy w rządzie, jak i opozycja zabiegali o to, by ustawa zasadnicza stała się przedmiotem konsensusu w Zgromadzeniu Konstytucyjnym, czego dowodem są słowa przewodniczącego Mustafy Ben Dżafarego: „Ta konstytucja jest fundamentem demokracji. Może nie jest idealna, może nie wszyscy dostali to, czego chcieli, ale na pewno jest wynikiem zgody" [Tunezja ma nowa... 2014]. Konstytucja Republiki Tunezyjskiej [Konstytucja z dnia 26 stycznia 2014] została przyjęta przez Zgromadzenie Konstytucyjne 26 stycznia 2014 r. - 200 głosami „,za” na 216 uprawnionych do głosowania, przy 12 ,przeciw” i 4 ,wstrzymujących się". Aby ustawa zasadnicza została uchwalona, zgodnie z prawem konieczne było jej poparcie ze strony 2/3 członków Konstytuanty. Gdyby do zgody nie doszło, konstytucja miała być poddana pod głosowanie w drodze referendum.

Tekst preambuły, stanowiącej integralną część konstytucji, przypomina zarówno o walce narodu tunezyjskiego o niepodległość w 1956 r., jak i walce o demokrację podczas rewolucji jaśminowej z 2011 r., afirmuje ponadto przywiązanie Tunezyjczyków do praw człowieka i ich tożsamości arabsko-muzułmańskiej. Arenga określa przy tym Tunezję jako państwo demokratyczne o republikańskiej formie rządów, w którym władza należy do ludu, a zasada podziału władz jest gwarantowana. Nakazuje również uczestnictwo Tunezji w unifikacji świata arabskiego, wspieranie ruchów wyzwoleńczych. Stwierdza też, że Tunezyjczycy muszą przyczyniać się m.in. do samopodtrzymującego (zrównoważonego) rozwoju²

1 Na jego czele stanął premier Mahdi Jomaa (pełniąc urząd od 29 stycznia 2014 r. do 6 lutego 2015 r.), a w skład zostali powołani wyłącznie niezależni eksperci. Z osiemnastu partii uczestniczących w rokowaniach między rządzącą umiarkowanie islamską partią Hizb an-Nahda a świecką opozycją jego kandydaturę poparło jedenaście z nich.

2 Zob. szerzej na temat aplikacji zasad rozwoju samopodtrzymującego (zrównoważonego) w Tunezji w: [Stachurska-Szczesiak 2019: 718]. 
Eksperci ocenili przyjęty dokument konstytucyjny jako najbardziej demokratyczny w świecie islamskim. Nowa konstytucja Tunezji, w której islam jest religią dominującą, a zdecydowana większość jej mieszkańców to muzułmanie, nie przyjęła szariatu (muzułmańskie prawo religijne), gwarantując wolność wyznania i religii, na co wskazuje art. $6 \mathrm{w}$ brzmieniu: „Państwo chroni religię, gwarantuje wolność wiary, sumienia i praktyk religijnych oraz gwarantuje neutralność meczetów i miejsc kultu oraz ich wolność od politycznej instrumentalizacji. Państwo angażuje się w rozpowszechnianie wartości umiaru i tolerancji, ochronę miejsc świętych i zapobieganie atakom na nie, podobnie jak angażuje się w zapobieganie takfirowi ${ }^{3}$ oraz szerzeniu nienawiści i przemocy, a także walce z nimi" [za: Rolewicz-Orpiszewska 2016: 18]. Zadeklarowano wręcz świeckość państwa w art. 2 w brzmieniu: „Tunezja jest państwem świeckim opartym na obywatelstwie, woli narodu i zwierzchności prawa. Do niniejszego artykułu nie wnosi się poprawek". Przy jednoczesnym zastrzeżeniu, że religią państwową wciąż pozostaje islam, jako że pozostawiono brzmienie art. 1 nowej konstytucji w wersji z 1959 r. („Tunezja jest wolnym, niezależnym i suwerennym państwem, którego religią jest islam, językiem arabski i gdzie istnieje republikański system rządów"), a w preambule podkreślono „przywiązanie narodu do nauk islamu”. Rezygnacja z prawa islamskiego jako podstawy nowej tunezyjskiej ustawy zasadniczej była istotną częścią politycznego kompromisu konstytucyjnego [zob. Pędziwiatr 2019: 86-90], ale rodziła też rozdźwięk między umiarkowanymi islamistami z Ennahdy a ultrakonserwatywną mniejszością muzułmańską - salafitami, którzy domagali się bezwzględnego obowiązywania muzułmańskiego prawa w państwie. Jak argumentowano, decyzja ta miała jednak „,na celu umocnienie zgody narodowej i sprzyjanie demokratycznej przemianie" [W Tunezji nie będzie... 2012] $]^{4}$. Tunezyjska formuła konstytucyjna o świeckości państwa jest jedyną jak dotychczas tego typu deklaracją wśród państw arabskich.

Konstytucja zapewnia równość kobiet i mężczyzn, co jest absolutnym novum w państwach arabskich. Artykuł 21 ustawy zasadniczej z 2014 r. (uchwalony 159 głosami $^{5}$ ) w brzmieniu: „Wszyscy obywatele, mężczyźni i kobiety, mają równe prawa i obowiązki oraz są równi przed prawem bez żadnej dyskrymina-

3 Takfir-nazywanie kogoś niewiernym. Zob.: Takfir, The Oxford Dictionary of Islam, [online], http://www.oxfordislamicstudies.com/article/opr/t125/e2319 [dostęp: 11.10.2019]; [Badar, Nagata, Tueni 2017]. W porewolucyjnej walce politycznej były wykorzystywane takfirowe fatwy odnoszące się m.in. do członków liberalnej opozycji. Zabójstwa będące ich wynikiem, w szczególności lewicowego polityka Szukriego Balajda, i presja międzynarodowa z tym związana przyczyniły się do konstytucyjnej negacji takfiru.

4 Tunezja nie oprze się o szariat. Salafici protestuja, 2012, „Wprost”, [online] https://www. wprost.pl/313090/tunezja-nie-oprze-sie-o-szariat-salafici-protestuja.html; KL, Tunezja ma nowa konstytucję. Gwarantuje wolność wyznania, 2014, „,Wprost”, [online] https://www.wprost.pl/433900/ tunezja-ma-nowa-konstytucje-gwarantuje-wolnosc-wyznania.html [dostęp: 11.10.2019].

5 Po uchwaleniu wszystkich artykułów projektu ustawy zasadniczej, które były przyjmowane zwykłą większością głosów, Zgromadzenie Konstytucyjne poddało pod głosowanie jej tekst w całości, z zachowaniem wymogu jej przyjęcia większością 2/3 głosów członków Zgromadzenia. 
cji”, nawiązuje do tradycji politycznej Tunezji, która wyprzedzała inne państwa muzułmańskie, jeśli chodzi o prawa kobiet. Większość praw kobiety uzyskały za panowania pierwszego prezydenta Habiba Bourgiby (m.in. wydanie w $1956 \mathrm{r}$. Kodeksu Statusu Osobistego ${ }^{6}$ ). Za jego rządów zmniejszył się wpływ religii na państwo (m.in. zakazano noszenia hidżabu w miejscach publicznych), zdelegalizowano poligamię, określono minimalny wiek dla kobiet na zawarcie małżeństwa (17 lat), zastrzegając obowiązek uzyskania na nie zgody, wprowadzono równe prawo do rozwodu, który może być przeprowadzany tylko przed sądem, a także ustanowiono równe prawa do opieki nad dziećmi po rozwodzie rodziców. Dużym osiągnięciem socjalnym pozostaje zrównanie zarobków kobiet i mężczyzn za pracę tej samej wartości, co nie jest tak oczywiste nawet w realiach europejskich. W 1997 r. wprowadzono zaś prawo wybieralności do parlamentu dla wszystkich obywateli, którzy mają choć jednego rodzica posiadającego obywatelstwo tunezyjskie, bez rozróżnienia, czy rodzicem tym jest ojciec, czy matka. Powołano też do życia Ministerstwo ds. Kobiety i Rodziny, Kobiece Centrum Badań, Dokumentacji i Informacji (CREDIF), Narodową Radę ds. Kobiet i Rodziny, jako instytucje monitorujące i kontrolujące wdrażanie w życie przepisów dotyczących praw kobiet [Dmitrowa 2010: 91-93].

Co istotne, ustrojodawca, kreując przepisy konstytucji z 2014 r., nie tylko potwierdził, ale i rozszerzył ich dotychczasowy zakres. Art. 46 stanowi bowiem, że: „Państwo zobowiązuje się do ochrony osiągniętych przez kobiety praw, wspiera je i rozwija. Państwo gwarantuje równość szans między mężczyznami i kobietami. Państwo dąży do równej reprezentacji kobiet i mężczyzn w wybieranych radach. Państwo podejmuje niezbędne środki celem wyeliminowania przemocy wobec kobiet”. Artykuł 34 potwierdza prawo kobiet „do wyboru, głosowania i kandydowania" oraz że państwo będzie dążyć do zagwarantowania reprezentacji kobiet w wybieralnych organach przedstawicielskich, z kolei art. 74 określający warunki biernego prawa w wyborach prezydenckich wyraźnie stanowi, że prawo ubiegania się o urząd Prezydenta Republiki „ma każdy wyborca płci męskiej i żeńskiej” spełniający określone literą prawa wymogi formalne. Ponadto art. 40 konstytucji sankcjonuje prawo dostępu do rynku pracy tak kobiet, jak i mężczyzn.

Realizując postanowienia konstytucji, w 2017 r. Tunezja jako pierwsza w regionie wprowadziła antyprzemocowe prawo. Nowe przepisy zakładają przede wszystkim, że przemoc domowa na tle seksualnym, fizycznym, moralnym czy ekonomicznym wobec kobiet nie będzie już traktowana jako sprawa prywatna, lecz państwowa. Oznacza to, że ofiary mogą liczyć na pomoc, przede wszystkim prawną, ze strony państwa. Oprócz tego władze mają prowadzić specjalne programy nastawione na zmianę mentalności tunezyjskiego społeczeństwa i promo-

6 Code du Statut Personel, [online] https://www.ilo.org/dyn/natlex/docs/ELECTRONIC/73374/74946/F-1287339442/TUN-73374.pdf [dostęp: 11.10.2019]. 
wanie zasad praw człowieka i równości płci. W tym samym roku z inicjatywy prezydenta Beji Caid Essebsiego zniesiono też zakaz małżeństwa z niewiernymi, który na podstawie prawa szariatu obowiązywał w Tunezji muzułmanki (do tej pory tylko mężczyźni mogli poślubiać niemuzułmanki) [Wójcik 2017]. Realizując zagwarantowaną w konstytucji równość płci, prezydent Essebsi zaproponował również, żeby kobiety miały takie same prawa dziedziczenia jak mężczyźni, zastępując tym samym system oparty na szariacie, który przyznawał córkom połowę spadku otrzymywanego przez synów ${ }^{8}$. Ważnym czynnikiem mającym stymulować aktywność kobiet w społeczeństwie, pozwalającym na zmianę ich pozycji, zwiększającym ich świadomość i poczucie niezależności społecznej, jest konstytucyjnie gwarantowany dostęp do edukacji. Artykuł 39 konstytucji wprowadził bowiem obowiązek edukacyjny do 16. roku życia.

W reakcji na doświadczenia autorytaryzmu przedrewolucyjnych rządów wprowadzono w art. 23 bezwzględny zakaz tortur („Państwo będzie chronić godność ludzką i integralność fizyczną oraz będzie zapobiegać torturom psychicznym i fizycznym. Stosowanie tortur jest zbrodnią, która nie ulega przedawnieniu”). Mniej stanowczo członkowie Zgromadzenia Konstytucyjnego opowiedzieli się w kwestii kary śmierci. Artykuł 22 konstytucji, przyjęty po kilkudniowej zaciętej dyskusji 135 głosami przy 28 przeciw (11 członków Zgromadzenia wstrzymało się od głosu $)^{9}$, pozostawia furtkę do stosowania kary śmierci, przyjmując brzmienie: „Prawo do życia jest święte i nienaruszalne, z wyjątkiem skrajnych przypadków, które prawo zdefiniuje”.

Tunezja przepisami ustawy zasadniczej z 2014 r. przyjęła mieszany (semiprezydencki) system rządów realizowany na podstawie zasady podziału władz. Władzę ustawodawczą powierzono jednoizbowemu parlamentowi Zgromadzeniu Przedstawicieli Ludowych liczącemu 217 deputowanych (z możliwością jej realizacji również w drodze referendum, jak stanowi art. 50 konstytucji), wybieranych w wyborach powszechnych i bezpośrednich na pięcioletnią kadencję. Wartym zauważenia jest konstytucyjnie gwarantowany status opozycji politycznej. Zgod-

7 Tunezja zakazuje przemocy wobec kobiet. Znika m.in. przepis o oczyszczeniu z zarzutów, gdy poślubi się ofiarę, [online], http://kobieta.gazeta.pl/kobieta/7,107881,22172500,tunezja-zakazuje-przemocy-wobec-kobiet-znika-m-in-przepis-o.html [dostęp: 14.10.2019].

8 Tunisia cabinet approves equal inheritance law, Memo Middle East Monitor, 2018, https://www. middleeastmonitor.com/20181126-tunisia-cabinet-approves-equal-inheritance-law/; ARB, Tunezja: Kobiety chca dziedziczyć jak mężczyźni, „Rzeczpospolita”, 2018, [online], https://www.rp.pl/ Spoleczenstwo/180319943-Tunezja-Kobiety-chca-dziedziczyc-jak-mezczyzni.html; L. Khalife, 5 times Tunisia proved it is a pioneer in women's rights, https://stepfeed.com/5-times-tunisia-proved-it-is-a-pioneer-in-women-s-rights-7320; https:/www.wiadomosc/2018-08-13/w-tunezji-kobiety-maja-zaczac-dziedziczyc-na-tych-samych-zasadach-co-mezczyzni/; M. Radlicki, Feministyczna Tunezja, Investafrica.pl 2019, http://www.investafrica.pl/2019/06/feministyczna-tunezja/ [dostęp: 14.10.2019].

9 Kl, Tunezja ma nowa konstytucję. Gwarantuje wolność wyznania, „Wprost” 2014, https:// www.wprost.pl/433900/tunezja-ma-nowa-konstytucje-gwarantuje-wolnosc-wyznania.html [dostęp: 17.10.2019]. 
nie z art. 60, opozycja winna stanowić integralną część składową Zgromadzenia Przedstawicieli Ludowych. Ma ona zagwarantowane odpowiednie instrumenty aktywności parlamentarnej i reprezentacji we wszystkich strukturach i organach wewnętrznych Zgromadzenia, w tym przewodnictwo w komisjach do spraw finansowych i spraw zagranicznych. W uzupełnieniu nie można nie wspomnieć również o konstytucyjnych gwarancjach pluralizmu politycznego (art. 35), prawa do zrzeszania się (art. 36) czy prawa zgromadzeń (art. 37) oraz wolności wypowiedzi (art. 31).

W okresie rządów przedrewolucyjnych, kiedy kolejno prezydenci Habiba Burgiba oraz Zine el-Abidine Ben Ali sukcesywnie starali się umacniać swą władzę w państwie, opozycja została praktycznie wyrugowana ze sceny politycznej, co prowadziło do konfliktów w państwie i zahamowania jego demokratycznego rozwoju. Podjęte z początkiem lat 60 . XX w. działania delegalizacyjne wobec najsilniejszych ugrupowań opozycyjnych spowodowały, że prezydencka partia Neo-Destur (przekształcona w 1964 r. w Partię Konstytucyjno-Socjalistyczną) stała się w zasadzie jedyną liczącą się formacją polityczną w państwie. Gdy na przełomie lat 60. i 70. XX w. w konsekwencji rosnącego niezadowolenia społecznego z sytuacji wewnętrznej i gospodarczej w państwie zaczęły powstawać formacje opozycyjne, nie mogły one działać legalnie, a ówczesne władze brutalnie starały się rozprawić z ich liderami [zob. szerzej Dziubiński 1994: 320 i n.]. Kolejne lata również nie były wolne od prób spychania opozycji poza margines sfery rządzenia państwem, realizowanych przede wszystkim przez procesy delegalizacyjne kolejnych partii, wytaczanie działaczom ruchów opozycyjnych publicznych procesów politycznych czy stosowanie jeszcze bardziej brutalnych środków represji bezpośredniej [Bojarczyk 2004: 105-107]. W tym kontekście podkreślenie konstytucyjnej roli opozycji i zagwarantowanie jej reprezentacji prawa uczestnictwa w pracach wszelkich gremiów parlamentarnych należy odczytywać szczególnie pozytywnie.

Na czele władzy wykonawczej stanął prezydent republiki wybierany przez naród w wyborach bezpośrednich na 5-letnią kadencję (z możliwością tylko jednej reelekcji ${ }^{10}$ ). Został on zaopatrzony w liczne prerogatywy oraz szerokie uprawnienia w dziedzinie bezpieczeństwa wewnętrznego i polityki zagranicznej. Prezydentowi przysługuje na czas jego kadencji immunitet sądowy, a wszelkie wszczęte wobec jego osoby procedury sądowe ulegają zawieszeniu na czas wykonywania przezeń mandatu. Dodatkowo zyskał immunitet materialny - zniesiona została bowiem jego odpowiedzialność za czyny związane z wykonywaniem funkcji i zadań przynależnych głowie państwa (art. 87 konstytucji). Przysługuje mu prawo

${ }^{10}$ W wyniku zmian konstytucyjnych z 1975 r. prezydentowi H. Burgibie stworzono możliwość pełnienia urzędu praktycznie dożywotnio. Od 1988 r. w wyniku zaś kolejnych nowelizacji ustawy zasadniczej prezydent mógł pełnić swój urząd maksymalnie przez trzy kadencje. Dziś zgodnie z art. 75 konstytucji z 2014 r. niedopuszczalne jest pełnienie funkcji głowy państwa więcej niż przez dwie kadencje i to bez względu na to, czy następują po sobie bezpośrednio. Z jednoczesnym zastrzeżeniem konstytucyjnym, że uregulowanie to nie podlega żadnym zmianom. 
tak inicjatywy, jak i weta ustawodawczego (art. 62 i art. 81 konstytucji). Nie ma ono jednak charakteru ostatecznego. W przypadku ustaw zwykłych ich ponowne uchwalenie wymaga bezwzględnej większości głosów członków parlamentu, jednak w przypadku ustaw organicznych wymagana jest już większość $3 / 5$ ich głosów. Może on również uczynić projekty ustaw dotyczące praw i swobód obywatelskich, czy traktatów międzynarodowych przedłożonych do ratyfikacji przedmiotem głosowania referendalnego (art. 82 konstytucji). Novum wprowadzonym przepisami konstytucji z 2014 r. pozostaje Trybunał Konstytucyjny, do którego prezydent może zwrócić się z wnioskiem o weryfikację konstytucyjności przedłożonego mu do promulgacji prawa (orzeczenia Trybunału Konstytucyjnego mają przy tym charakter ostateczny), jak też przed którym ponosi on odpowiedzialność konstytucyjną (por. art. 88 konstytucji). W przypadku rozwiązania parlamentu zyskuje prawo do wydawania dekretów z mocą ustawy.

Drugim członem egzekutywy pozostaje rząd, którego skład tworzą: prezes Rady Ministrów, ministrowie oraz sekretarze stanu powoływani przez prezydenta republiki z poparciem parlamentu. Konstytucja zastrzega (art. 89), że obsada stanowisk ministrów: spraw zagranicznych i obrony narodowej, wymaga uprzedniej konsultacji ze strony premiera z prezydentem. Członków rządu wiąże zasada niepołączalności stanowisk tak z mandatem deputowanego, jak i w zakresie wykonywania wszelkich innych funkcji zawodowych. Premier pełni funkcję kierowniczą w rządzie, przewodniczy jego posiedzeniom (gdy nie bierze w nich udziału prezydent republiki), jest również konstytucyjnie wskazany do zastępowania głowy państwa w jej obowiązkach, gdy zaistniałaby tymczasowa przeszkoda w sprawowaniu urzędu prezydenta (por. art. 83 konstytucji). Rada Ministrów ponosi odpowiedzialność polityczną przed prezydentem i Zgromadzeniem Przedstawicieli Ludowych, a finansową przed Izbą Obrachunkową.

Jedną z kluczowych zasad przyjętych uregulowaniami nowej konstytucji pozostaje reguła niezawisłości sędziowskiej i niezależności sądów mających za zadanie „stać na straży sprawiedliwości, nadrzędności Konstytucji, suwerenności prawa i ochrony praw i wolności”. Obywatelom konstytucyjnie (art. 108) gwarantowane jest prawo do sądu, prawo do obrony oraz wprowadza się co najmniej dwuinstancyjną i opartą na regule jawności procedurę sądową. Obowiązuje przy tym zasada domniemania niewinności (art. 27), zakaz bezpodstawnego aresztowania (art. 29) oraz prawo do humanitarnego traktowania więźniów (art. 30). Wymiar sprawiedliwości w Tunezji sprawują sądy powszechne, sądy administracyjne i sądy finansowe, a do przestępstw wojskowych powoływane są sądy wojskowe. Jednocześnie wprowadzono zakaz tworzenia sądów wyjątkowych i korzystania z trybów doraźnych jako naruszających zasady rzetelnego procesu sądowego. Strażnikiem niezależności tunezyjskiego sądownictwa uczyniono Najwyższą Radę Sądownictwa. 


\section{REALIZACJA UREGULOWAŃ KONSTYTUCYJNYCH TUNEZJI U PROGU 2020 ROKU}

Osiem lat po demonstracjach obywateli, które doprowadziły do ucieczki dyktatora Bena Alego i upadku jego partii RCD (Zgromadzenie Demokratyczno-Konstytucyjne) sytuacja w Tunezji pozostaje nadal niejasna. Tunezyjskie demonstracje na przełomie grudnia $2010 \mathrm{r}$. i stycznia $2011 \mathrm{r}$. paryscy redaktorzy nazwali poetycko „rewolucją jaśminową”, ale ci, którzy ją stworzyli lub przeżyli, woleli nazwę „rewolucja wolności i godności”" ${ }^{11}$. O ile jaśmin nie ma innej przyszłości niż zwiędnąć czy obumrzeć, to wolność i godność można przewidzieć w dalekiej przyszłości [Cavaillès 2019]. Obok wolności, sprawiedliwości oraz ładu to godność stała się główną dewizą zapisaną w art. 4 Konstytucji Tunezji z 27 stycznia 2014 r. ${ }^{12}$ Wolność, przynajmniej ekspresji, jest nadal zdobywana w Tunezji, zaś godność tak naprawdę jeszcze się nie wykluła.

Transformacja polityczna Tunezji, nagrodzona w 2015 r. Pokojową Nagrodą Nobla ${ }^{13}$ nadal postępuje, ale rozwój gospodarczy jest powolny i nierównomierny. Ponadto pogorszenie stanu bezpieczeństwa jest przedmiotem coraz większej troski o debatę publiczną, a wewnętrzne regiony państwa są w dużej mierze wyłączone z rozwoju gospodarczego.

Przez ostatnie kilka lat kryzys gospodarczy i wysokie bezrobocie w Tunezji powstrzymywały nadzieję na lepsze życie o wiele bardziej niż kiedykolwiek wcześniej. 24 grudnia 2018 r. doszło do starć między policją a demonstrantami, które odbyły się w miejscowości al-Kasrajn (fr. Kasserine) w środkowo-zachodniej części Tunezji. Zamieszki wybuchły po tym, jak 32-letni dziennikarz dokonał samospalenia [Dziennikarz podpalit się... 2018]. Aktem tym Abderrazak Zorgui chciał zwrócić uwagę na trudną sytuację społeczną oraz dał wyraz utracie nadziei na to, że zmiany w jego państwie kiedykolwiek się dokonają, zgodnie z tym co przyniosły ze sobą zdobycze rewolucji jaśminowej. Odwołując się do trudnych warunków życia w swoim regionie, uznanego za jeden z najbiedniejszych w państwie, wezwał swoich rodaków do kolejnej rewolucji przeciwko władzom w Tunisie. Fakt ten dowodzi, że osiem lat po „wybuchu nadziei” na odnowienie jest jeszcze wiele do zrobienia. Można nawet powiedzieć, że u progu $2020 \mathrm{r}$. sytuacja jest gorsza. Jeśli w 2010 r. podobny czyn dokonany w Sidi Bu Zajd (fr. Sidi Bouzid) w centralnej części Tunezji i ofiara 26-letniego sprzedawcy ulicznego Mohammeda Bouaziziego utorowały drogę do obalenia dyktatury w państwie, to

${ }^{11}$ Zob. szerzej o problemie dysproporcji między regionami Tunezji: [Stachurska-Szczesiak 2019: 292, 296, 426-479].

12 Art. 4 w części pt. „ogólne zasady” Konstytucji Republiki Tunezji 27 stycznia 2014 r., [online] https://mjp.univ-perp.fr/constit/tn2014.htm [dostęp: 04.11.2019].

${ }_{13}$ Le dialogue national tunisien, Prix Nobel de la paix 2015, "Le Temps" 2015, [online], https://www.letemps.ch/monde/dialogue-national-tunisien-prix-nobel-paix-2015; F. Bobin, En Tunisie, miracle ou mirage?, "Le Monde" 2016, [online], https:/www.lemonde.fr/international/ article/2016/03/03/en-tunisie-miracle-ou-mirage_4876142_3210.html [dostęp: 04.11.2019]. 
śmierć 32-letniego mężczyzny z rodziny, która niekoniecznie była w potrzebie, pozostała jedynie aktem wojowniczym. Podczas transmisji wideo na Facebooku na kilka minut przed śmiercią A. Zorgui zwrócił się do tych, którzy śledzili go w sieci społecznościowej słowami: „Dla bezrobotnych z al-Kasrajn rozpocznę rewolucję, dokonam samospalenia! Aby potępić »kłamstwo«, którym żyje młodzież miasta przez osiem lat. To kłamstwo obiecujące lepsze życie, które nigdy nie nastąpiło" [Cavaillès 2019].

Dzisiaj południowe regiony Republiki Tunezji pozostają nadal „wydziedziczone". Różnice w poziomach ubóstwa między wybrzeżem a środkową i południową częścią państwa tylko się powiększyły. Według danych z 2016 r. w Tunezji występują duże różnice w poziomie ubóstwa, zarówno globalnego, jak i skrajnego między regionami, co jest widoczne zwłaszcza między stroną zachodnio-południową a resztą kraju. Regiony środkowo-zachodnie i północno-zachodnie są najbiedniejsze w państwie, a wskaźniki ubóstwa szacuje się odpowiednio na 8,4\% i 6,4\% znacznie powyżej średniej krajowej wynoszącej $2,9 \%$. Analizowana na poziomie gubernatorstwa dysproporcja w ubóstwie nadal się utrzymuje. I tak, ogólny wskaźnik ubóstwa jest 10-krotnie wyższy w miastach Kairuan (fr. Kairouan) (34,9\%) i Al Kaf (fr. Kef) (34,2\%) niż w mieście Tunis (3,5\%) [Mogouri 2018: 28].

Tunezyjska konstytucja opracowana po upadku dyktatora i ogłoszona na początku 2014 r. przewiduje pomoc dla tych dotkniętych obszarów. Artykuł 12 stanowi, że „państwo działa w celu zapewnienia sprawiedliwości społecznej, rozwoju samopodtrzymującego (zrównoważonego) i równowagi regionalnej, uwzględniając wskaźniki rozwoju i zasadę pozytywnej dyskryminacji”. O ile aktywności związane z realizacją zasad koncepcji rozwoju samopodtrzymującego (RS) są realizowane przy dużym wsparciu ze strony europejskich i międzynarodowych programów [Stachurska-Szczesiak 2019: 584-634], to jednak o pozostałych celach do osiągnięcia zawartych w art. 12, głównie tych związanych z niwelowaniem dysproporcji rozwojowych wewnątrz państwa, można powiedzieć, że pozostają one jak na razie w sferze marzeń tysięcy Tunezyjczyków.

Niezwykle trafne są słowa Elyés Jouiniego, francusko-tunezyjskiego profesora ekonomii: „Można odnieść wrażenie, że ze strony rządu, polityki jako całości lub klasy ekonomicznej nie było świadomości” [Cavaillès 2019]. Być może to polityczne blokady powstrzymały żar wszystkich lub odwrotnie, konsensus między przeciwnymi partiami politycznymi (postępową Nida Tounes z islamską Ennahdą, która ponownie pojawiła się w polityce tunezyjskiej po upadku Bena Alego) okazał się swoistym hamulcem dla przemian gospodarczo-społecznych i wyrównywania szans rozwojowych między regionami. Konsensusy te mogły doprowadzić do postępu politycznego, lecz na poziomie gospodarczym i społecznym utrzymują się bardzo rozbieżne stanowiska. E. Jouini trafnie stwierdził, że ,jedynym sposobem na utrzymanie tych umów według rządzącej elity nie jest dotykanie żadnego z tematów, który jest wrażliwy" [Cavaillès 2019].

Jeśli weźmie się pod uwagę badania przeprowadzone w 2017 r. przez Open Sigma na tunezyjskiej opinii publicznej na temat trendów społeczno-polityczno- 
-gospodarczych w tym państwie, dają one wyobrażenie o oczekiwaniach Tunezyjczyków, wzmacniając powyższą obserwację. Raport ten ujawnia, że prawie 90\% ankietowanych Tunezyjczyków jest zaniepokojonych kwestią nierówności w państwie ${ }^{14}$, a nawet widzą porażkę w niwelowaniu regionalnych różnic [Mogouri 2018: 9]. Zdecydowana większość opinii publicznej, przy 64\% wszystkich ankietowanych uważa, że w ich państwie wzrosły nierówności [Mogouri 2018: 9]. Ponad 30\% opinii publicznej straciła nadzieję na rozwiązanie problemu nierówności. 31\% ma mieszane zdanie i uważa, że nawet jeśli istnieją rozwiązania, trudno je znaleźć. Nadzieje na jakiekolwiek rozwiązania utrzymują się zaledwie w 20\% opinii publicznej [Mogouri 2018: 10].

Wyżej wspomnianym nastrojom społecznym nie sprzyjają wskaźniki gospodarcze, a dokładnie koszty utrzymania i stopa bezrobocia wynosząca w drugim kwartale 2019 r. 15,3\% (634,9 tys. całkowitej siły roboczej $)^{15}$. W porównaniu do sytuacji z 2018 r. wskaźnik ten był niemal identyczny, bo wynosił $15,4 \%{ }^{16}$. Dane te podważają morale państwa, dając obraz stagnacji gospodarczej. W ciągu dwóch lat dinar tunezyjski spadł o 60\% w stosunku do dolara, inflacja w $2018 \mathrm{r}$. osiągnęła 7,8\% i nieznacznie spadła do 6,7\% w 2019 r. [Tunisie: Le taux ... 2018]. Liczby te tym bardziej zaskakują, gdyż dotyczą także tych regionów, w których występują pewne bogactwa naturalne (co jest widoczne zwłaszcza w branży fosforanów dotkniętej brakiem inwestycji w przemysł wydobywczy) [Krami 2018]. Artykuł 13 Konstytucji Tunezji co prawda odwołuje się do zasobów naturalnych ${ }^{17}$, lecz wymaga nowego podejścia, zmiany myślenia na temat wykorzystywania zasobów naturalnych, która powinna się dokonać nie na poziomie społeczeństwa obywatelskiego, lecz głównych ośrodków decyzyjnych. W kontekście wspomnianych wyników gospodarczych Tunezji oraz nierówności społecznych i konieczności uwzględniania zasad RS w rozwoju gospodarczym, produkcja fosforanów w praktyce jest stosunkowo problematyczna. Z jednej strony to strategiczna gałąź gospodarki ze względu na dużą ilość dostępnych zasobów na terytorium tego państwa, a co za tym idzie rosnące zatrudnienie pracowników w tym sektorze

14 Prowadzenie systematycznych badań na temat nierówności w Tunezji nie jest łatwym zadaniem. Jedną z trudności jest różnorodność niezbędnych wskaźników: zamożność, wynagrodzenie, dochód, konsumpcja lub wydatki, praktyki kulturowe, poziom edukacji, stan zdrowia, dostęp do finansowania, dostęp do podstawowej infrastruktury, ochrona socjalna itd. W rzeczywistości nierówność nie ogranicza się do jednego wskaźnika, ale jest identyfikowana przez przecięcie całego zestawu uzupełniających się wymiarów. Do tej kategorii trudności dodaje się brak danych wymaganych do oceny niektórych aspektów. Są to ważne wymiary nierówności, pozostawiając wiele martwych punktów.

15 https://www.huffpostmaghreb.com/entry/le-taux-de-chomage-stagne-a-15-3-au-deuxieme -trimestre-2019_mg_5d56a891e4b056fafd0ac7c7 [dostęp: 10.11.2019].

16 https://cdn.radiofrance.fr/s3/cruiser-production/2019/01/b2230290-a019-47ca-923d-cca0554f414c/838_visactu-tunisie-les-chiffres-cles-de-leconomie-168510080d8.webp [dostęp: 13.11.2019].

17 Art. 13 w brzmieniu: „Zasoby naturalne są własnością mieszkańców Tunezji. Suwerenność państwa nad tymi zasobami sprawowana jest w jego imieniu”. 
(w 2010 r. - 14600 pracowników; w 2017 r. - 25758 pracowników) [Quel avenir pour... 2018], z drugiej nieakceptowana społecznie i środowiskowo przez wysoce uświadomione społeczeństwo tunezyjskie, które dało wyraz swojemu niezadowoleniu 14 stycznia $2011 \mathrm{r}^{18}$, wymuszając niejako potrzebę modernizacji oraz dyskusję na temat bardziej zrównoważonych metod wydobywczych. Reakcją na oczekiwania społeczne w tej sprawie są słowa eksperta tunezyjskiego przemysłu wydobywczego Kaisa Daliego, wyrażone podczas konferencji zorganizowanej 12 maja 2018 r. na temat przyszłości sektora wydobywczego fosforanów: „,społeczne i ekologiczne kryteria rozwoju samopodtrzymującego (zrównoważonego) są kryteriami nowymi, które wymagają czasu i pieniędzy, aby można byłoby je wprowadzić z życie" [Quel avenir pour... 2018].

Zła gospodarka i ponure perspektywy dla państwa tunezyjskiego to ocena także liberalnych ekspertów zebranych przez Tunezyjską Radę ds. Analiz Ekonomicznych, Arabskich Konsultantów Finansowych (AFC) oraz Niemiecką Agencję Współpracy Międzynarodowej (GIZ) 28 lutego 2019 r. w Tunisie. Dokonano przeglądu danych makroekonomicznych, które nie napawają optymizmem. Zanotowano skromny wzrost, lecz mimo to uznany przez ekspertów za raczej optymistyczny. W 2018 r. gospodarkę napędzały głównie turystyka/restauracje $(+8,9 \%)$ i rolnictwo $(+9,8 \%)$. Jeśli chodzi o ten drugi sektor, to eksport oliwy z oliwek odegrał rolę lokomotywy, osiągając prawie połowę wartości eksportu produktów rolnych (730 mln euro - stan na 31 grudnia 2018 r.). Ale jest to plon drzew oliwnych osiągających szczyt tylko jeden raz na dwa lata, czyniąc kolejny sezon mniej produktywnym [Tunisie: les chiffres... 2019]. Bilans handlowy nieznacznie się zmienia. Import wzrósł do 39,9\%, a eksport zaledwie do 13,7\%. Bardziej niż import martwi spadek udziału sektora energetycznego w bilansie handlowym (z 14,10\% w $2010 \mathrm{r}$. do 5,7\% w 2018 r.; w produktach górniczych/fosforanowych z 9,2\% do 3,4\%) [Tunisie: les chiffres... 2019]. Jest to spowodowane wyżej wymienionymi kłopotami związanymi z niedoinwestowaniem w tym sektorze.

W tym kontekście gospodarczym i społecznym osiem lat po rewolucji jaśminowej społeczeństwo tunezyjskie, jak również jego elita polityczna zostały postawione przed faktem nowych wyborów parlamentarnych oraz przyśpieszonych wyborów prezydenckich. Do tej pory Tunezja nie była jednak w stanie ,wyprodukować mężczyzn i kobiet”, którzy mogliby z powodzeniem nią rządzić. Od 2011 r. tylko dwóm podmiotom politycznym i dwóm liderom udało się pozostać u władzy: islamskiej Partii Odrodzenia (Ennahda) na czele z Raszidem Gannuszim (Rached Ghannouchi) oraz modernistycznej Partii Wezwanie Tunezji (Nida Tounes) utworzonej w 2012 r. przez późniejszego Prezydenta Republiki Beji Caid Essebsiego. Jednak od czasu euforii, będącej następstwem obalenia Bena Alego, atmosfera wciąż oscyluje między smutkiem a katastrofą.

18 Tunezyjskie ruchy społeczne doprowadziły do zmniejszenia wydobycia fosforanów z $8 \mathrm{mln}$ ton w 2010 r. do 4 mln ton w 2017 r. 
Nagła śmierć B.C. Essebsiego 25 lipca 2019 r. skutkowała koniecznością rozpisania nowych przyśpieszonych wyborów prezydenckich, zaplanowanych pierwotnie na 17 listopada 2019 r. W kontekście śmierci dotychczasowego przywódcy Tunezji został wykorzystany po raz pierwszy art. 84 Konstytucji Tunezji, którego ustęp 2 stwierdza, że „W przypadku śmierci lub trwalej niezdolności do pracy lub jakiegokolwiek innego powodu wakatu, Trybunał Konstytucyjny zbiera się niezwłocznie [...], informuje Przewodniczącego Zgromadzenia Przedstawicieli Ludowych (ARP), który niezwłocznie działa jako Prezydent, na okres tymczasowy, przez co najmniej 45 dni, a najdłużej 90 dni". Do czasu przeprowadzenia nowych wyborów prezydenckich, które odbyły się w dwóch turach 15 września (tura pierwsza) oraz 13 października (tura druga), funkcje tymczasowego prezydenta pełnił zgodnie z Konstytucją Przewodniczący ARP - Mohamed Ennaceur. Po pierwszej turze spośród 22 kandydatów aspirujących o fotel Prezydenta Republiki Tunezji zostało wyłonionych dwóch, tj. konserwatywny prawnik Kais Saied ${ }^{19}$ oraz biznesmen Nabil Karoui ${ }^{20}$. Mimo iż jest niewiele dostępnych badań socjologicznych lub statystyk, głosowanie młodzieży stało się ważnym czynnikiem w tych wyborach prezydenckich (37\% głosowało na K. Saieda w pierwszej turze). „Mamy zarówno upolitycznioną młodzież poszukującą innej kultury politycznej, jak i bardziej zmarginalizowaną młodzież, która również chce radykalnej zmiany", powiedział Mohamed Sahbi Khalfaoui, profesor nauk politycznych na Uniwersytecie w Jendouba [Blaise 2019]. Drugi kandydat, N. Karoui, przyciągną1 głosy starszych i defaworyzowanych grup społecznych oraz część młodzieży tej bardziej obojętnej [Blaise 2019]. Druga tura wyborów prezydenckich zakończyła się miażdżącą przewagą K. Saieda, na którego głosowało 72,7\% wobec 27,3\% oddanych na jego politycznego rywala N. Karouia. 24 października 2019 r. osoba dotychczas pełniąca obowiązki głowy państwa została zastąpiona prawowitym, wybranym w demokratycznych wyborach prezydentem.

Z kolei wybory legislacyjne, które odbyły się 6 października 2019 r., doprowadziły ponownie do zwycięstwa Ennahdy z 52 mandatami, która wraz z 38 mandatami uzyskanymi przez islamską partią N. Karouia - Serce Tunezji (Qalb Tounes) tworzą dużą siłę polityczną. Jednak wynik ten niebędący większością (90 mandatów na 217) oznacza, że partie bliskie ideologicznie są zmuszone do wchodzenia w sojusze. Trzecią w kolejności partią z 22 mandatami jest Socjaldemokratyczna Partia Attayar (Prąd Demokratyczny) założona przez działacza na rzecz praw człowieka - Mohammeda Abbou, zaś Al-Karama, nowo utworzony ruch islamo-populistyczny Seifeddine Makhloufa, prawnika znanego z obrony podejrzanych salafitów, zdobył 21 mandatów [Législatives en Tunisie... 2019]. 17 mandatów zdobyła Partia Wolnego Przeznaczenia antyislamskiej prawniczki

${ }^{19}$ Uczony konstytucjonalista podczas kampanii sprytnie kultywował swoją odmienność, unikając polityki i występując bez poparcia jakiejkolwiek partii. Jego mowa nie odnosi się do religii, ale częściej do prawa. Zasadniczo określa się mianem ultrakonserwatywnego, ale nie islamistycznego.

${ }^{20}$ Ścigany za uchylanie się od płacenia podatków i prania brudnych pieniędzy. 
Abiry Moussi. Tym samym będąca dużym rozczarowaniem podczas kandydowania w wyborach prezydenckich A. Moussi, która broniła reżimu ,zdetronizowanego" prezydenta Zine el Abidine Ben Alego, została wybrana posłem do Tunisu.

W sumie 6 października spośród $7 \mathrm{mln}$ uprawnionych do głosowania zagłosowało 2,9 mln wyborców. Niezależna wyższa instancja do spraw wyborów Isie ogłosiła wskaźnik uczestnictwa na poziomie 41,3\% [Législatives en Tunisie... 2019]. Wyniki te potwierdzają z jednej strony gotowość do kontynuowania, mimo poważnych trudności, zmiany systemu w kierunku umacniania demokracji, z drugiej strony zaś widoczne rozdrobnienie parlamentu Tunezji między głęboko odmiennymi formacjami zwiastuje trudne negocjacje w celu utworzenia rządu, a następnie stanowienia prawa.

Wyborcy tunezyjscy wybrali nietypowego prezydenta, zdecydowali się na parlament bez większości i zniszczyli dotychczasową klasę polityczną. Ich pragnienie zmian pchnęło ich w obszar ryzyka, którego prawdopodobnie nie ocenili w wystarczającym stopniu podczas głosowania. Chociaż sondaże przeprowadzono przykładowo, wynik odpowiada ekspresji w kierunku tradycyjnych podziałów politycznych.

Wyjaśnianie sojuszy, zmniejszanie deficytu, łagodzenie napięć społecznych to główne wyzwania, którym klasa polityczna wybrana w jesiennych wyborach do parlamentu, a także nowy prezydent stawili czoła w $2020 \mathrm{r}$.

\section{KONKLUZJE}

W kontekście zdobyczy rewolucji jaśminowej, której wyrazem pozostaje Konstytucja Republiki z 2014 r. oraz sytuacja gospodarczo-społeczna i polityczna, powstaje pytanie o perspektywę rozwoju Tunezji. Oprócz dość pesymistycznych wizji, istnieje także inny sposób analizy postępów poczynionych od stycznia 2011 r. Najbardziej logicznym i najbardziej neutralnym jest cofnięcie się. Kto mógł poważnie wyobrazić sobie, że w tak krótkim czasie w historii, a po podjęciu decyzji o zmianie całego systemu, większości zasad gry i aktorów, ścieżka ta będzie wybrukowana różami, że niemal spontaniczne nastąpi generowanie polityk, a zmiana po ponad pół wieku znieczulenia ogólnego pojawi się w mgnieniu oka [Yahmed 2018]. Demokracja, indywidualne wolności, nowa konstytucja wśród najnowocześniejszych w Afryce i świecie arabskim, niezaprzeczalny postęp w kierunku równości mężczyzn i kobiet, pewna sztuka dialogu i konsensusu, odpowiedzialność nowego pokolenia, odrodzenie się społeczeństwa obywatelskiego - ta lista osiągnięć nie może być niebrana pod uwagę.

Tunezyjczycy zdecydowanie wolą odłożyć wszystko na dalszy plan, aby na nowo odkryć swoje państwo i instytucje. Osiągnięcie celu będzie wymagało cierpliwości, być może pięciu, dziesięciu lat lub więcej. Biorąc pod uwagę kontekst historyczny, w jakim buduje się demokracja w Tunezji, począwszy od odzyskania niezależności od metropolitalnej Francji, kontekst gospodarczy i realizacja glo- 
balnych celów wynikających z koncepcji rozwoju samopodtrzymującego (zrównoważonego), wysoki poziom świadomości społeczeństwa tunezyjskiego, dzisiaj mimo licznych zawirowań na poziomie stabilności politycznej państwa będącego w trakcie transformacji nie ma powodu, aby wątpić w ich ostateczny sukces.

Title: The Political System of the Republic of Tunisia after the Jasmine Revolution

\begin{abstract}
The 2011 peaceful overthrow of Tunisian longtime dictator Zine el-Abidine Ben Ali (known as the Jasmine Revolution) inspired the Arab Spring. Since then, Tunisia has introduced far-reaching democratic reforms. In the West, the country has been perceived as one of the few Middle East and Maghreb countries where the Arab Spring has been successful. The aim of the article is to analyze the evolution of political conditions that took place after the Jasmine Revolution through the prism of the establishment of the new Constitution of the Republic of Tunisia in 2014 and the implementation of its principles at the beginning of 2020. The starting point of such a research goal, apart from systemic issues, is to capture the changes that took place in the Republic of Tunisia, taking into account economic and social conditions and their assessment. In this methodological context, the new constitution, which embodies the expectations of the Tunisian society after 2011, strengthens and sets a new framework for the democratic process of the country.
\end{abstract}

Keywords: political system of Tunisia, Jasmine Revolution, Arab Spring, Constitution of the Republic of Tunisia, transformation

\title{
BIBLIOGRAFIA
}

1. ARB (2018), Tunezja: Kobiety chca dziedziczyć jak mężczyźni, „Rzeczpospolita”, [online], https://www.rp.pl/Spoleczenstwo/180319943-Tunezja-Kobiety-chca-dziedziczyc-jak-mezczyzni. html [dostęp: 14.10.2019].

2. Badar M., Nagata M., Tueni T. (2017), The Radical Application of the Islamist Concept of Takfir, "Arab Law Quarterly", vol. 31, s. 132-160 [online] https://www.geopoldia.org/images/ bedas-tueni2.pdf [dostęp: 11.10.2019]. DOI: https://doi.org/10.1163/15730255-31020044.

3. Blaise L. (2019), Election présidentielle en Tunisie: une jeunesse en quête de changement, "Le Monde Afrique", [online], https://www.lemonde.fr/afrique/article/2019/10/13/election -presidentielle-en-tunisie-une-jeunesse-en-quete-de-changement_6015307_3212.html [dostęp: 19.11.2019].

4. Bobin F. (2016), En Tunisie, miracle ou mirage?, "Le Monde", [online], https://www.lemonde. fr/international/article/2016/03/03/en-tunisie-miracle-ou-mirage_4876142_3210.html [dostęp: 04.11.2019].

5. Bojarczyk B. (2004), System polityczny Republiki Tunezji, [w:] Adaptacja wartości europejskich w państwach islamskich, red. A. Ziętek, K. Stachurska, Wyd. UMCS, Lublin.

6. Cavaillès T. (2019), Tunisie : une Révolution pour rien ?, France Kulture, [online], https://www. franceculture.fr/politique/tunisie-une-revolution-pour-rien [dostęp: 30.10.2019].

7. Dmitrowa M. (2010), Kobieta arabska w krajach Maghrebu w świetle ograniczeń nakładanych na nia przez spoleczeństwo, „Acta Universitatis Wratislaviensis, Przegląd Prawa i Administracji” LXXXII, No 3171, Wrocław. 
8. Dziennikarz podpalit się w proteście przeciwko władzom Tunezji, (2018), https://wiadomosci. radiozet.pl/Swiat/Tunezja.-Dziennikarz-Abderrazak-Zorgui-podpalil-sie-w-protescie-przeciwko-wladzom [dostęp: 06.11.2019].

9. Dziubiński A., (1994), Historia Tunezji, Wyd. Ossolineum, Wrocław.

10. KL (2014), Tunezja ma nowa konstytucję. Gwarantuje wolność wyznania, „Wprost” 27.01, [online] https://www.wprost.pl/433900/tunezja-ma-nowa-konstytucje-koniec-z-szariatem.html [dostęp: 10.10.2019].

11. Konstytucja Republiki Tunezji z dnia 1 czerwca 1959 r. z późniejszymi zmianami, [online], http://confi nder.richmond.edu/admin/docs/Tunisiaconstitution.pdf [dostęp: 10.10.2019].

12. Konstytucja Republiki Tunezyjskiej z dnia 24 stycznia 2014, [online], http://biblioteka.sejm. gov.pl/konstytucje-swiata-tunezja/ [dostęp: 10.10.2019].

13. Krami K. (2018), Quel avenir pour l'industrie du phospate en Tunisie, 23.05, [online], http:// kapitalis.com/tunisie/2018/05/23/quel-avenir-pour-lindustrie-du-phosphate-en-tunisie/ [dostęp: 06.11.2019].

14. Le dialogue national tunisien, Prix Nobel de la paix 2015, (2015), “Le Temps", [online], https:// www.letemps.ch/monde/dialogue-national-tunisien-prix-nobel-paix-2015 [dostep: 04.11.2019].

15. Législatives en Tunisie: Ennahdha en tête avec 52 sièges, selon les résultats officiels, (2019), "Jeune Afrique", [online], https://www.jeuneafrique.com/841028/politique/legislatives-en-tunisie-ennahdha-en-tete-avec-52-sieges-selon-les-resultats-officiels/ [dostęp: 19.11.2019].

16. MJ (2012), W Tunezji nie będzie szariatu, „Newsweek”, [online] https://www.newsweek.pl/ polska/tunezja-odrzuca-szariat-w-tunezji-nie-bedzie-szariatu/pkt9hyy [dostęp: 11.10.2019].

21. MK (2014), Tunezja ma nowa konstytucję, „Gazeta Wyborcza” 27.01, [online], https://wyborcza. pl/1,75399,15342243,Tunezja_ma_nowa_konstytucje.html [dostęp: 10.10.2019].

17. Mogouri A. (2018), Déséquilibres régionaux et inégalités sociales en Tunisie. Axes et actions prioritaires, Tunis.

18. Pędziwiatr K. (2019), Przemiany islamizmów w Egipcie i Tunezji w cieniu arabskiej wiosny, Wyd. Znak, Kraków.

19. Quel avenir pour l'industrie du phosphate en Tunisie?, (2018), Kapitalis, http://kapitalis.com/ tunisie/2018/05/23/quel-avenir-pour-lindustrie-du-phosphate-en-tunisie/ [dostęp: 19.11.2019].

20. Radlicki M., Feministyczna Tunezja, (2019), Investafrica.pl, http://www.investafrica.pl/2019/06/ feministyczna-tunezja/ [dostęp: 14.10.2019].

21. Rolewicz-Orpiszewska A. (2016), System konstytucyjny Tunezji, Wyd. Rozpisani.pl, Łódź.

22. Stachurska-Szczesiak K. (2019), Rozwój samopodtrzymujący w polityce Unii Europejskiej w państwach Maghrebu, Wyd. UMCS, Lublin.

23. Tunisie: Le taux d'inflation se stabilise en septembre à 6,7\%, (2019), Webmanagercenter, [online], https://www.webmanagercenter.com/2019/10/04/439666/tunisie-le-taux-dinflation-se-stabilise-en-septembre-a-67/ [dostęp: 13.11.2019].

24. Tunisie: les chiffres de 2018 augurent une année délicate pour 2019, (2019), "Politique Économique", [online], https://www.jeuneafrique.com/744953/economie/tunisie-les-chiffres-de2018-augurent-dune-annee-delicate-pour-2019/ [dostęp: 19.11.2019].

25. Wójcik J. (2017), Tunezja zezwoli kobietom na malżeństwo z niewiernymi, [online] https:// euroislam.pl/tunezja-zezwoli-kobietom-na-malzenstwo-z-niewiernymi-i-pelne-prawa-w-dziedziczeniu [dostęp: 10.10.2019].

26. Yahmed M.B., (2018), Tunisie: l'optimisme est la foi des révolutions, “Jeune Afrique”, [online], https://www.jeuneafrique.com/mag/675056/politique/edito-tunisie-loptimisme-est-la-foi-des -revolutions/ [dostęp: 22.11.2019]. 